\title{
DEMOCRACIA E ACESSO À INFORMAÇÃO NAS COMPRAS PÚBLICAS MUNICIPAIS POR MEIO DO PREGÁO ELETRÔNICO
}

\author{
DEMOCRACY AND ACCESS TO INFORMATION IN MUNICIPAL PUBLIC PURCHASES \\ THROUGH ELECTRONIC PREACHING
}

\author{
Rosângela Angelin \\ Universidade Regional Integrada do Alto Uruguai e das Missões - URI, Campus Santo Ángelo, RS, Brasil, \\ rosangela@gmail.com
}

Jocelit Zborowski

Faculdade CNEC Santo Ângelo - CNEC, RS, Brasil, jocelitozb@gmail.com

DOI: http://dx.doi.org/10.31512/gesto.v8i2.56

Recebido em: 18/08/2019

Aceito em: 12/03/2020

\begin{abstract}
Resumo: O Estado Democrático de Direito trouxe muitas novidades, entre elas, a possibilidade da participaçáo mais ativa da sociedade civil nas gestóes governamentais e, consequentemente, do controle exercido sobre essas. No âmbito da participação nas Administraçôes Públicas, uma das formas de atuação da sociedade civil é através do controle dos atos administrativos exercidos a partir das informaçóes que o próprio Estado disponibiliza para a população. Assim sendo, adotando-se o método hipotético dedutivo, baseado em leituras de obras e artigos, bem como de teorias da Administração Pública e de legislaçôes vigentes a pesquisa em voga pretende analisar como o direito fundamental à informação é viabilizado nas Administrações Públicas no Brasil, qual é o papel do pregão eletrônico nas compras públicas e se esse contribui para a ampliação do controle e efetivação da democracia. Os resultados da pesquisa denotam para o fato de que a consolidação da democracia perpassa pelo direito fundamental do acesso à informação, o qual possibilita o exercício da cidadania, vinculando o mesmo ao princípio da transparência nas compras públicas, atualmente viabilizada através da modalidade licitatória pregáo eletrônico, que possibilita um completo acompanhamento do cidadáo no tocante aos gastos públicos e, consequentemente, uma possível interferência e controle dos gastos públicos, exercendo a prerrogativa da cidadania.
\end{abstract}

Palavras-chave: Direito Fundamental. Direito à Informação. Compras Públicas. Democracia. Licitaçôes.

Abstract: The Democratic State of Law brought many new features, among them, the possibility of more active participation by civil society in governmental management and, consequently, of the control exercised over them. Within the scope of participation in Public Administrations, one of the ways in which civil society acts is through the control of administrative acts exercised based on information that the State itself makes available to the population. Therefore, adopting the hypothetical deductive method, based on readings of works and articles, as well as theories of public administration and current legislation, the current research intends to analyze how the fundamental right to information is made possible in Public Administrations in Brazil, what is the role of electronic trading in public procurement and whether it contributes to the expansion of democracy control and effectiveness. The results of the research denote the fact that the consolidation of democracy runs through the fundamental right of access to information, which enables the exercise of citizenship, linking it to the principle of transparency in public purchases, currently made possible through the electronic auction bidding modality, which makes it possible for the citizen to be fully monitored with regard to public spending and, consequently, possible interference and control of public spending, exercising the prerogative of citizenship.

Keywords: Fundamental Right. Right to Information. Public Procurement. Democracy. Biddings. 


\section{Introdução}

As gestóes públicas brasileiras, independente da esfera - seja ela federal, estadual ou municipal-, estão submetidas ao Regime Jurídico Administrativo, o qual contempla a observância de vários princípios na condução das atividades públicas, os quais estão contemplados na Constituição Federal. Um desses é o princípio da legalidade, que obriga todos agentes públicos, na administraçáo da res publica, a seguirem fielmente os ditames previstos no ordenamento jurídico. Os princípios possuem a dupla função das prerrogativas e sujeiçôes administrativas. Funcionam como forma de fornecer poderes como também impor limitaçóes ao administrador, o que se configura em uma forma de controle e limite do poder dentro de um Estado democrático. Por conseguinte, quando se aborda o tema envolvendo o acesso à informaçáo frente às compras públicas, a essência dessas sujeiçôes estaria materializada no princípio da transparência da ação governamental, bem como da probabilidade de se poder participar da fiscalização desses atos públicos de forma igualitária. Assim, poder participar das gestóes públicas e ter acesso a direitos básicos para assim fazê-lo é uma premissa do regime político democrático brasileiro, já anunciado no artigo $1^{\circ}$, caput e da Constituição Federal de 1988 e no parágrafo único desse mesmo artigo que se encarregou de proclamar a soberania popular, que pode ser exercida de forma direta, indireta ou mista.

Tanto dispositivos constitucionais, quanto legislaçóes e normas que compóe o ordenamento jurídico versam sobre a participação popular nas Administraçôes Públicas. Ocorre que, enquanto dispositivo normativo princípio lógico, a democracia é de fácil compreensão e aceitação, não ocorrendo o mesmo no mundo fático, onde a implementação e efetivação dos princípios democráticos, em especial no tange aos órgãos públicos, apresentam inúmeros obstáculos impeditivos e/ou que burlam o espírito do referido princípio constitucional.

No âmbito da participação nas Administrações Públicas, uma das formas de atuação da sociedade civil é através do controle dos atos administrativos exercidos a partir das informaçóes que o próprio Estado disponibiliza para a população. Assim sendo, adotando-se o método hipotético dedutivo, baseado em leituras de obras e artigos, bem como de teorias da organização pública e de legislaçôes vigentes a pesquisa em voga pretende analisar como o direito fundamental à informação é viabilizado nas Administraçóes Públicas no Brasil, qual é o papel do pregão eletrônico nas compras públicas e se esse contribui para a ampliação do controle e efetivação da democracia. Para alcançar esse objetivo a pesquisa aborda, num primeiro momento, o direito à informação. Num segundo, para então ater-se à temática principal, o direto ao acesso à informação nas compras públicas. $\mathrm{O}$ resultado seria descobrir se esse, efetivamente teria o condão de garantir a aplicação dos princípios num Estado democrático.

\section{Direito Fundamental à Informação e a Lei de Acesso à Informação diante do princípio da transparência das gestões públicas}

Direito à Informação faz parte do rol dos Direitos Fundamentais apregoados no artigo $5^{\circ}$ da Constituição Brasileira (BRASIL, 1988) é um avanço no processo de efetivação da participação qualificada dos cidadãos em espaços públicos, uma vez que para participar, é preciso ter acesso a informaçóes que embasem os temas que estão sendo debatidos nos diversos setores da Administração Pública. O discurso sobre os Direitos Humanos e Direitos Fundamentais está situado no plano histórico da época moderna e 
estão amplamente ligados aos problemas envolvendo o direito dos seres humanos, a democracia e a paz. Sobre a importância dos Direitos Humanos, atenta Peres Luño:

Los Derechos Humanos suelen venir entendidos como un conjunto de facultades e instituciones que, en cada momento histórico, concreta las exigencias de la dignidad, la libertad y la igualdad humanas, las cuales deben ser reconocidas positivamente por los ordenamientos jurídicos a nivel nacional e internacional. En tanto que con la noción de los Derechos Fundamentales se tiende a aludir a aquellos Derechos Humanos garantizados por el ordenamiento jurídico positivo, en la mayor parte de los casos en su normativa constitucional, la que suele gozar de una tutela reforzada (PÉREZ-LUÑO, 2013, p. 42).

Denota-se que os Direitos Fundamentais são frutos de resistência ao poder exacerbado e despótico de governantes que, na Idade Média, frente ao feudalismo, exerciam gestóes com bases absolutistas. Com as Revoluçôes Francesa e Estadunidense, o cenário se altera: forma de governo republicana é a novidade nas gestôes de Estados e, apregoa-se os direitos fundamentais individuais - voltados, em especial, para a proteção dos indivíduos frente ao Estado. Assim, os Direitos Fundamentais são direitos de caráter históricos, frutos de reivindicações e contestaçóes de poderes, em especial absolutistas e, além de apregoados, esses direitos normalmente são positivados nas Constituiçôes (BOBBIO, 2000, p. 169). Inicialmente, estes direitos se voltavam para o aspecto individualista, principalmente de exigência de proteção das pessoas diante das arbitrariedades e tiranias do Estado (CORREAA, 2000). Mais adiante, os Direitos Fundamentais assumiram um caráter social e coletivo obrigando os Estados e, em especial, as gestóes públicas a garantir e viabilizar direitos a coletividades sociais que buscavam melhores condiçóes estruturais de vida dentro do Estado. Atualmente foram agregados ao rol de direitos fundamentais, os direitos difusos, entre eles a democracia.

$\mathrm{Na}$ história moderna das transformaçóes do Estado e de sua forma de gerir o bem público, a busca pelo bem-estar social e a participação republicana efetiva da sociedade civil têm acompanhado essas mudanças e se configurando na sua mais atual versão: o Estado Democrático de Direito, o qual tem o dever de promover a igualdade formal e isonômica, a inclusão social, assegurando, sobretudo, a efetivação dos direitos fundamentais. Traçando o caminho normativo das Administraçôes Públicas, a Constituição Federal de 1988 evidenciou os princípios que irão alicerçar todas as gestôes, ou seja, o princípio da legalidade, da moralidade, da publicidade da eficiência, previstos no caput do artigo 37 (BRASIL, 1988).

Embasadas nas premissas acima citadas, as gestóes públicas precisam ter presente, de forma bastante contundente, o princípio da transparência de seus atos e os mandamentos da Lei de Acesso à Informação (LAI) nas compras públicas, uma vez que o direito à informação tem como intuito assegurar a aplicação de direitos fundamentais. Numa análise contextual do Estado, percebe-se que a concepção dos direitos fundamentais determina a própria significação do Poder Público e de sua atuação diante da sociedade. $\mathrm{Na}$ vida política, os direitos fundamentais gozam de maior proteção quanto maior for a intervenção e abrangência de ação do Estado de Direito, e ao contrário, quanto menor o Estado de Direito, menor será a proteção aos direitos de fundamentais (PÉREZ LUÑO, 2013. p. 15-16).

O Direito Fundamental à Informação, constitucionalizado no Brasil, se configura como um direito crucial para o exercício da democracia. Piovesan $(2009$, p. $105 ; 106 ; 120)$ pondera que, tanto o bem-estar social, quanto o direito que os indivíduos possuem ao desenvolvimento dependem diretamente da distribuição e uso equitativo da informação, do conhecimento e da cultura. Neste contexto, o direito ao acesso à informação surge como um direito humano fundamental e encontra-se protegido inclusive 
por tratados internacionais. Destaca-se que junto ao direito à informação estão contemplados os direitos de liberdade de buscar as informaçóes, receber e difundir as ideias de toda a natureza, sendo pressuposto lógico da existência de uma sociedade livre.

Neste interim, a informação é designada como o conjunto de modalidades difundidas ou disponibilizadas para o público, materializada através de notícias ou demais elementos de conhecimentos como ideias ou opiniōes, bem como situaçóes de interesse geral ou até mesmo particular, remetendo a dois direitos, o de informar e o de ser informado (SILVA, 2009, p. 244), sendo tal direito fundamental para a preservação da verdade dos fatos, em especial, no que tange a questôes do âmbito público, conforme pondera Lafer:

Observo também como a transparência do público, por meio do direito à informação, que está ligado à democracia como forma de vida e de governo, é uma condição de possibilidade para a sobrevivência da verdade factual, na qual se baseia a interação e o juízo político (LAFER, 1991, p. 29).

Mello aponta para a necessidade de não haver ocultamento das informações de caráter público dentro de Estados Democráticos, uma vez que o poder se encontra na vontade popular e, através da informação, é possível que o cidadão participe de forma democrática nas decisôes e desenvolvimento do Estado (MELLO, 2013, p. 117).

O acesso público a informaçôes oficiais é o corolário da transparência na prestação de contas públicas, fazendo com o direito à informação esteja amplamente ligado com o princípio da transparência. Desta forma, nos tratados internacionais nos quais o Brasil é signatário, prega-se a adoção do princípio da transparência como forma de proporcionar, ao cidadáo, o acompanhamento e conhecimento do exercício dos atos administrativos.

O direito à informação se configura como um princípio fundamental uma vez que proporciona o controle da atuação estatal na sua gestão. A Constituição Federal (BRASIL, 1988) trata a informação como direito de informar, de se informar e ser informado. A redação do artigo 220 assim dispóe: "A manifestação do pensamento, a criação, a expressão e a informação, sob qualquer forma, processo ou veículo não sofrerão qualquer restrição, observado o disposto nesta Constituição". Já o artigo $5^{\circ}$, inciso XIV, da referida Constituição, determina que o acesso à informação e o resguardo ao sigilo da fonte em casos de exercício profissional. No tocante ao direito de ser informado, previsto no artigo $5^{\circ}$, inciso XXXIII, da Constituição Federal, este versa sobre a garantia do cidadão em obter dos órgãos públicos informaçóes, quer do seu interesse, quer interesse geral ou mesmo do interesse coletivo. Esse direito representa um dos pilares do atual sistema democrático e, nesse contexto, é uma ferramenta indispensável para o pleno exercício da cidadania (BRASIL, 1988).

Não se pode olvidar que o artigo $37, \mathbb{3} 3^{\circ}$, inciso II, da referida Constituição determina que a lei disciplinará as formas de participação do usuário na Administração Pública Direta e Indireta, através de regulação do direito de acesso dos usuários a registros administrativos e a informaçóes sobre atos de governo. Além desse dispositivo, o artigo 216, $\$ 2^{\circ}$ determina que "Cabem à Administraçáo Pública, na forma da lei, a gestão da documentação governamental e as providências para franquear sua consulta a quantos dela necessitem" (BRASIL, 1988).

Portanto, a noção de democracia está interligada com a ideia de fluidez de informaçôes, sendo primordial para a manutenção dos direitos fundamentais. A ausência do direito à informação em uma 
sociedade sentencia a população à ignorância, à alienação, limitando sua capacidade de formar opinião ou mesmo acompanhar e fiscalizar os atos públicos. Atualmente, o acesso à informação tem sofrido modificaçóes bastante significativas através da utilização das novas tecnologias, as quais acabam por propiciar um acesso mais seguro e rápido às informaçôes, buscando contribuir para ampliar a cidadania.

Com a finalidade de regulamentar os dispositivos constitucionais relacionados ao direito à informação previstos no artigo $5^{\circ}$, inciso XXXIII, artigo $37, \$ 3^{\circ}$, inciso II e o artigo $216, \$ 2^{\circ}$, foi editada a Lei 12.527 (BRASIL, 2011), conhecida como Lei de Acesso à Informação (LAI), que apresentou inúmeras inovações no ordenamento jurídico brasileiro. Através da referida lei, expressamente foi estabelecido o direito de acesso à informaçáo como regra, sendo que o direito ao sigilo foi tratado como verdadeira exceção. Trata-se de lei nacional, aplicável a União, Estados, Distrito Federal e Municípios, bem como demais órgãos da Administração Pública Direta e Indireta de todos os Poderes. A norma também se aplica às entidades privadas que recebam recursos públicos, diretamente do orçamento ou mediante subvenções sociais, contrato de gestão, termo de parceria, convênios, acordo, ajustes ou outros instrumentos congêneres, conforme previsão contida no Artigo 20 (BRASIL, 2011).

Como forma de aplicação da lei em questão, foi editado o Decreto 7.724, de 16 de maio de 2012, que regulamentou a LAI no âmbito do Poder Executivo federal. Decorrente da necessidade de proporcionar efetividade à publicidade e ao desenvolvimento do controle social da Administração Pública, o referido Decreto contemplou duas espécies de transparência: a ativa e a passiva. A transparência ativa é a divulgação de informaçóes à sociedade, por iniciativa da própria Administração Pública, de forma espontânea, independente de qualquer solicitação. Essa divulgação deverá ser através de meios de fácil acesso ao cidadão tais como sítios de internet. A transparência ativa está prevista no artigo 7 , ressaltando que "É dever dos órgãos e entidades promover, independente de requerimento, a divulgação em seus sítios na Internet de informaçóes de interesse coletivo ou geral por eles produzidas ou custodiadas" (BRASIL, 2012).

Já na transparência passiva, a Administração Pública divulga informaçóes sob a demanda em atendimento às solicitações da sociedade. Para esses casos, os órgãos públicos deverão criar Serviço de Informaçôes ao Cidadão (SIC), conforme determinação do artigo $9^{\circ}$. A transparência passiva possui previsão no artigo 10 e seguintes que determinam os procedimentos e mecanismos vinculados à solicitação de informações por parte dos cidadãos. Destaca-se que para as requisiçôes de acesso à informação, conforme previsão do artigo $10 \$ 2^{\circ}$ da LAI, "Os órgãos e entidades do poder público devem viabilizar alternativa de encaminhamento de pedidos de acesso por meio de seus sítios oficiais na internet”. Além disso, tais requisições não precisam ser justificadas e nem há a necessidade de demonstrar interesse, conforme previsão do artigo $10 \$ 3^{\circ}$ : "São vedadas quaisquer exigências relativas aos motivos determinantes da solicitação de informaçôes de interesse público". Especificamente no tocante ao acesso referente às licitaçôes, o artigo 7º, inciso VI determina o direito de obter: "informação pertinente à administração do patrimônio público, utilização de recursos públicos, licitação, contratos administrativos” (BRASIL, 2012).

Os órgãos públicos, como forma de transparência ativa, deverão implementar uma seção específica em seus sítios na internet que possibilitem divulgação das licitaçôes realizadas e em andamento, com editais, anexos e resultados, além dos contratos firmados e notas de empenho emitidas, conforme previsão do Inciso IV do artigo 7o do Decreto 7.724 (BRASIL, 2012). Ocorre que a partir da promulgaçáo da Constituição Federal de 1988, a informação pública e a sua divulgação começaram a receber um novo 
tratamento. Até então, decorrente do regime ditatorial imposto para a sociedade, havia a cultura do segredo onde a gestão e a informação pública eram pautadas pelo princípio do risco da sua circulação, cabendo sempre à chefia do órgão público deliberar pela sua divulgação ou não (BRASIL, 1988).

Diante do exposto, destaca-se que, diante de uma participação mais ativa da sociedade nas questóes públicas, o Estado está cada vez mais sendo pressionado a dar condiçóes para o florescimento desta verdadeira escola de cidadania proporcionada pela LAI. A sua implementaçáo será um processo árduo e incremental, mas com certeza afetará profundamente as raízes do modelo patrimonialista que tanto prejudica a modernização do Brasil (ABRUCIO, 2012). Assim sendo, a seguir será vislumbrado o acesso à informação nas compras públicas.

\section{Compras públicas através do pregão eletrônico: um olhar a partir do direito da informação e da democracia}

A sociedade contemporânea tem trazido novos desafios para todos os setores da sociedade. Administração Pública tem buscado se adequar às novas necessidades da sociedade, sendo que o atual modelo de gestão administrativa contempla uma série de atividades e serviços que busca, cada vez mais, uma gestão da res publica voltada à satisfação dos interesses públicos. A sociedade está vivendo um novo momento de acelerado desenvolvimento tecnológico, e a velocidade da comunicação instantânea tem alterado as rotinas individuais e coletivas, aumentando a competição industrial e causando transformaçôes na sociedade. Informaçáo e tempo passaram a ser considerados sinônimos de produtividade, custos e poder.

As novas tecnologias têm proporcionado um resultado positivo no que se refere ao pluralismo político, bem como ao acesso à informação dos órgãos públicos, possibilitando que as pessoas possam participar das decisóes de maneira mais democrática (SANCHÉZ BRAVO, 2010, p. 18). Para Pérez Luño (2004, p. 12) as novas tecnologias podem e devem projetar a democracia a um novo nível, onde a relação cidadão-estado é mais fecunda e transparente, bem como propiciar novos benefícios para a sociedade, ao permitirem uma maior propagação do conhecimento, tornando mais sólido o desenvolvimento da cidadania e dos ideais de uma democracia.

Diante da busca desses anseios coletivos e individuais, o Estado necessita primeiramente proporcionar meios e condiçôes para que a população utilize esses equipamentos. No mesmo sentido, o Estado necessita utilizar os meios modernos de comunicação para a prestação de um serviço eficiente e atualizado, com maior qualidade, controle e garantia dos direitos dos administrados e da dignidade dos indivíduos, como é o caso do direito à informação. Para que possa prestar esses serviços com eficiência, a Administração Pública necessitará dispor de um sistema que permita uma comunicação segura (SANCHÉZ BRAVO, 2007, p. 97).

Já passou o tempo em que o setor público era sinônimo de atraso, lentidão, filas intermináveis e burocracia. Evidentemente que estas características ainda existem, mas a tendência é a sua diminuição gradual face ao avanço das novas técnicas de informática. Essas novas Tecnologias da Informação e Comunicação (TIC), entre elas a internet, os telefones móveis e as redes de computadores, propiciam o alavancar de uma sociedade onde a informação e o conhecimento estão mais disponíveis (BRAGA, 
et al., 2008). Desta prestaçấo de atividade estatal não presencial decorre um novo conceito da forma de administrar.

O desenvolvimento contínuo da internet foi uma das mais significativas inovaçôes na tecnologia da informação, sendo que no âmbito da Administração Pública tem propiciado a transparência dos atos públicos, bem como garantido um maior acesso à informaçôes para as pessoas que são administradas e a possibilidade de efetivação do controle democrático por parte dos cidadãos (SANCHÉZ BRAVO, 2007, p. 90; 94), tornando-se numa importante ferramenta para permitir a comunicação entre Administração e administrados. O surgimento do Governo Eletrônico ou e-Gov para prestar informaçóes aos cidadãos tem buscado trabalhar para efetivar, por meio da tecnologia, uma relação mais direta, transparente e participativa entre as instituiçóes governamentais e o cidadão.

Como descrito por Vaz (2007, p. 56), "os autores vinculam a noção de governo eletrônico diretamente à utilização da Internet ou de outro meio de interconexão eletrônica pelas organizaçóes públicas", estando esse meio vinculado à prestação de serviços voltados para a informação, 24 horas por dia. Em decorrência de suas novas açôes, ao mesmo tempo em que está proporcionando uma nova geração de serviços públicos, também colabora com uma maior propagação da informação, permitindo um maior acompanhamento da sociedade e criando espaços que propiciam o diálogo e a participação democrática (BRAGA, et al., 2008, p. 6).

$\mathrm{Na}$ esteira de utilizar a tecnologia da informação, o governo federal implementou a modalidade pregão na sua forma eletrônica. Através do Sistema Comprasnet, todas as compras públicas federais, independente de modalidade, são cadastradas nesse portal. Há de se destacar que obrigatoriamente é nesse portal que são realizadas as sessôes de pregão eletrônico. Os demais Estados-membros possuem portais próprios como o LicitaNet do Estado de Minas Gerais, a Bolsa Eletrônica de Compras do Estado de São Paulo (BEC) e a Central de Licitaçôes do Estado do Rio Grande do Sul (CELIC RS), entre outros. Por sua vez, os Municípios, na ausência de portais próprios, utilizam o portal www.cidadecompras, que foi criado pela Confederação Nacional dos Municípios (CNM). É comum a utilização com o intuito de tornar-se o Portal Oficial de Compras Eletrônicas dos Municípios Brasileiros. Além desses existem o Licitaçôes-e, site do Banco do Brasil e Licitaçóes Caixa, da Caixa Econômica Federal, entre outros.

As informaçôes disponibilizadas por esses portais podem contribuir para a promoção da cidadania pela facilitação do acesso e o exercício de direitos: direito à informação de interesse particular; direito aos serviços públicos; direito a ser ouvido pelo governo; direito ao controle social do governo e direito à participação na gestão. $\mathrm{O}$ uso das websites municipais para o atendimento ao cidadão necessariamente "não confere cidadania, mas pode contribuir para o seu avanço, considerando que a construção da cidadania é um processo de permanente renovaçáo e ampliação de suas frentes e possibilidades” (VAZ, 2007, p. 17).

O horizonte atual da cidadania, de acordo com Pérez Lunó (2004, p. 11), orienta e circunscreve os padrões de seu exercício, é determinado pelo desenvolvimento das novas tecnologias da informação e comunicação. O mesmo autor define que cidadania, direitos fundamentais e Estado de Direito, possuem íntima relação entre si, pois são realidades que condicionam e se implicam mutuamente.

Pode-se destacar que o fundamento do direito a informaçáo, elevado como um direito humano, reside no fato de que a autoridade administrativa exerce atividades delegadas pelo cidadão decorrente da eleição, sendo que tais atividades públicas são mantidas pelo contribuinte através dos impostos. Dessa 
forma, o cidadão e o público em geral devem possuir o "direito de saber como o poder está sendo usado e como o dinheiro está sendo gasto. Mais do que isso, o cidadão tem o direito de influenciar e participar nos processos decisórios sobre matérias de interesse público" (MARTINS, 2011, p. 11).

Portanto, para a efetivação de compras públicas o Artigo 37 da Constituição Federal (BRASIL, 1988), determina que as mesmas deverão ser precedidas de prévia licitação, salvo situações excepcionais que impossibilitem ou inviabilizem sua realização. A regulamentação do inciso XXI do Artigo 37 da Constituição Federal resultou na Lei Ordinária 8.666, de 21 de junho de 1993 que institui normas gerais para a licitação e contratos da Administração Pública, pertinentes a obras, serviços, compras, alienaçóes e locaçôes aplicáveis à administração federal, estadual e municipal, estendendo ainda às autarquias, fundações públicas e demais entidades que direta ou indiretamente estivessem ligadas ao Governo (BRASIL, 1993).

Mesmo diante das alteraçóes feitas à Lei 8.666 (BRASIL, 1993), essa ainda é a principal lei em vigor que trata das contrataçóes públicas. Ela regula as formas e os procedimentos a serem adotados para a aquisição do objeto da licitação, bem como os critérios de escolha das modalidades e os tipos de julgamentos a serem adotados para realizar o certame licitatório. A ideia original da lei era dar uma resposta a uma série de escândalos das contrataçóes públicas. Para tanto, o texto exagerou no detalhamento das exigências e do rito do certame, abrindo espaço para as diversas interpretaçóes que, normalmente, resultam em litígio, tornando assim, o processo moroso.

A referida lei possui algumas peculiaridades no tocante à divulgação dos seus instrumentos convocatórios mais precisamente nos procedimentos aplicáveis à modalidade convite e à contratação direta. A divulgação dos atos posteriores das contrataçôes, a divulgação dos conteúdos das demais propostas, bem como cópias das atas, possuem regramentos específicos de cada órgão. Na maioria das vezes, a solicitação de tais documentos inevitavelmente esbarrava na burocracia, e quando os atendimentos aos pedidos não eram negados, simplesmente ficavam sobestados por falta de pessoal ou de tempo para a remessa das respostas por parte do órgão licitante (BRASIL, 1993).

Assim, com o intuito de agilizar o procedimento licitatório e possibilitar uma maior eficiência e economicidade às compras públicas, bem como uma publicizaçáo mais veloz e eficaz dos atos, foi criada uma nova modalidade de licitação denominada de pregão, inserida no ordenamento jurídico pela Lei 10.520 (BRASIL, 2002), através de duas formas: presencial ou eletrônica, sendo obrigatória apenas para os órgáos do governo federal. A nova modalidade veio para atender a celeridade e transparência exigidas nos processos licitatórios. Inicialmente na forma presencial e posteriormente na forma eletrônica, tal ferramenta colocada à disposição dos administradores representou um marco nas compras públicas, pois possibilitava, entre outras características, a reduçáo dos preços inicialmente ofertados, bem como agilizava os procedimentos uma vez que apresentava uma inversão das fases de habilitação e julgamento das propostas de preços. Além disso, houve uma considerável redução dos prazos recursais, pois o recurso contra os atos do órgáo licitador era restrito aos presentes no certame.

A forma presencial do pregão eletrônico exige que os interessados estejam fisicamente presentes na sessáo pública ou que se façam representar. Caso algum licitante envie as propostas e não compareça fisicamente ou no caso do seu representante não possuir poderes específicos para a participação na sessão, automaticamente estará fora das fases de lances e da interposição de recursos (JUSTEN FILHO, 2005, p. 87). Essa forma de licitar é duramente criticada pelas empresas localizadas geograficamente distantes 
dos órgãos licitadores, além do que as informações, tais como atas, preços, planilhas e documentos de habilitação ficam restritas aos presentes na sessão. Já o pregão na forma eletrônica, a realização da sessão é feita via internet, assim possibilitando a participação de empresas de qualquer localidade, pois tanto os agentes públicos como as empresas interessadas praticam todos os atos em meios virtuais. Nessa forma de pregão, não há necessidade de produção de documentos em papel, nem mesmo o comparecimento físico dos licitantes nos locais onde a sessão está sendo realizada (JUSTEN FILHO, 2018, p. 508).

A modalidade pregão na sua forma eletrônica destaca-se diante da ampla publicidade do certame e a transparência dos atos administrativos e dos documentos que registram a licitação, pois qualquer pessoa, seja outro contribuinte ou mesmo o cidadáo, da sua sede ou da sua residência, tem a prerrogativa de acompanhar o desenvolvimento da sessão e acessar todos os documentos como as propostas de preços, documentos de habilitação, atas da sessão e demais atos, bastando para isso um simples acesso gratuito ao provedor que está gerenciando os atos da sessão. A referida forma traz vantagens para aumentar a transparência dos processos de compras e aquisiçóes pela Administração, além de reduzir fraudes e, por conseguinte, atos de improbidade e imoralidade administrativa (VASCONCELO, 2006).

O pregão eletrônico, apesar de ter seu uso obrigatório na Administração Pública federal, é pouco utilizado nas esferas municipais. A maioria das críticas apontadas para essa modalidade decorre da falta de conhecimento das suas vantagens e a não aplicação dessa no âmbito municipal, ainda encontra justificativas superficiais voltadas para a falta de pessoal treinado ou mesmo falta de condiçóes técnicas. Apesar das modernas ferramentas tecnológicas colocadas à disposição, em algumas licitaçôes municipais, para efetuar as contrataçôes públicas, ainda se encontram dados que comprovam a utilização das modalidades previstas na Lei 8.666 (BRASIL, 1993), com destaque ao convite, sem mencionar as diversas contrataçóes diretas por dispensa de licitação. Outros utilizam a modalidade de pregão, entretanto, na forma presencial. Isso evidenciaria de um modo direto um direcionamento do procedimento, pois esta forma de licitar exige a presença física dos participantes no processo licitatório, privilegiando, de certa forma, os participantes locais.

Entretanto, o administrador público, quer diante do regramento, quer diante das situaçóes de exceção, ao utilizar os mecanismos para efetuar uma compra pública, deverá sempre realizar suas condutas nos princípios balizadores da Administração Pública, em especial, deverá obedecer aos princípios específicos das licitações. Além do rol constante do artigo 37, da Constituição Federal (BRASIL, 1988), no artigo $3^{\circ}$ da Lei no 8.666 (BRASIL, 1993) há uma relação taxativa dos principais princípios norteadores dos atos da Administração Pública quando esta realiza uma compra pública. Aliado a esses, o incipiente princípio da transparência determina a ampla divulgação da informação, disponibilizando o acesso a todos os atos administrativo.

Os atos administrativos são orientados por princípios de observância obrigatória a todos os administradores públicos. Com o processo de compras públicas ocorre o mesmo. Por ser tratar de um procedimento que visa a obtenção de um produto, contratação de um serviço ou realização de uma obra, entre outros objetos, o mesmo sempre acaba sendo alvo de análise pelos órgãos de controle e pela mídia. Geralmente o cidadão toma conhecimento desses atos, somente quando ocorre uma divulgação, normalmente negativa, dos procedimentos superfaturados envolvendo o dinheiro público. 
Com o intuito de moralizar cada vez mais esses procedimentos administrativos, além dos princípios constitucionais expressos e dos existentes nos diversos atos normativos, novas regras de conduta surgiram no contexto para dar uma maior clareza aos procedimentos de gastos públicos. E é exatamente nesse contexto que surge a modalidade pregão na sua forma eletrônica. Trata-se de uma das mais modernas ferramentas de proporcionar a ampla transparência dos atos inerentes ao procedimento licitatório, proporcionando instantaneamente informações gratuitas, precisas e em tempo real, para a sociedade, órgão de controle, demais licitantes e ao cidadão.

Importante se faz ponderar que, a não utilização do pregão na forma eletrônica para realizar compras públicas, invariavelmente, resulta em direcionamento de licitações. Quando isso não ocorre, invariavelmente, salvo algumas raras exceçóes, decorrente do uso das demais formas e modalidade licitatórias, o cidadão fica impedido de obter as informaçóes primordiais para fazer o acompanhamento dos atos públicos, pois as informaçôes sobre licitaçóes disponibilizadas nos sítios na internet de alguns órgãos públicos apresentam apenas a divulgação do instrumento convocatório e raramente disponibilizam o resultado com a identificação do licitante vencedor e o valor obtido. O incipiente princípio da transparência faz surgir a ideia de que informação não pode e não deve ficar adstritas às paredes internas da repartiçáo pública. Assim, como forma de garantir um dos direitos humanos fundamentais, o direito a informação surge como uma ferramenta para o cidadão acompanhar e fiscalizar os gastos públicos.

\section{Considerações finais}

No Estado Democrático de Direito, se torna evidente que a utilização das modernas ferramentas de comunicação, entre elas, a utilização da Internet, para a prestação de serviços e oferecimento de informaçôes aos cidadãos pelos entes públicos, está indissociavelmente ligada à noção de promoção de direitos de cidadania. Destaca-se que as informaçôes disponibilizadas pelos portais públicos podem contribuir para a promoção da cidadania pela facilitação do acesso e o exercício de direitos: direito à informação de interesse particular; direito aos serviços públicos; direito a ser ouvido pelo governo; direito ao controle social do governo e direito à participação na gestão. $\mathrm{O}$ simples uso das websites municipais para o atendimento ao cidadáo, necessariamente, náo vai promover a participaçáo cidadã por si só, mas poderá servir de incentivo para tal.

O acesso à informação é um dos mecanismos de efetivação da democracia, sendo que o fundamento desse direito reside no fato de que a autoridade administrativa, executora de atividades delegadas pelo cidadão decorrente da eleição, tem o dever de praticar os seus atos de uma forma mais transparentes possível. Essas ações são inerentes às atividades públicas, pois são mantidas pelo contribuinte através dos impostos. Dessa forma, o cidadão é portador do direito de ser informado sobre como está sendo gasto o dinheiro nas compras públicas e assim, através do controle social, exercer o seu direito de participação nas decisóes públicas. No tocante às compras públicas, denotam a predileção, em nível municipal, das modalidades licitatórias tradicionais, com utilização de documentos físicos e propostas de preços realizadas com a presença físicas dos licitantes. A lei que regula sua aplicabilidade é rígida no tocante à forma de publicizar os editais, porém omissa na divulgaçáo dos atos e demais documentos, cabendo essa opção ao órgão licitador. 
Fato é que, a LAI contempla uma série de obrigatoriedades formais, entre as quais se destaca a disponibilização de dados referentes a licitaçôes. Essa lei foi e está sendo um grande avanço para o direito fundamental à informação. Mesmo de caráter obrigatório, até o presente momento, nem todos os órgãos públicos estão engajados na implementação integral da LAI. As informaçóes sobre licitaçóes disponibilizadas nos sítios na internet de alguns Municípios apresentam apenas a divulgação do instrumento convocatório e raramente disponibilizam o resultado com a identificaçáo do licitante vencedor e o valor obtido.

Para preencher essa lacuna informativa e proporcionar um moderno e eficaz meio de acompanhamentos das contrataçóes públicas, todos os órgãos da Administração Pública federal utilizam exclusivamente, para compras de bens e serviços comuns, a modalidade pregão, na forma eletrônica. Decorrentes das vantagens já elencadas essa modalidade é uma das principais ferramentas utilizadas para moralizar as compras públicas e proporcionar um amplo acompanhamento dos atos administrativos federais. A lei instituidora do pregáo, facultou o seu uso para os entes estaduais e municipais, os quais poderão criar legislação própria. Assim, a modalidade licitatória pregão, na sua forma eletrônica, utilizada nas compras públicas, vem a ser um destaque como mecanismo capaz de fornecer informaçóes pertinentes aos atos licitatórios, possibilitando que todo cidadão possa ter acesso e, com isso, promovendo a possibilidade de efetivação da democracia através da participação popular.

\section{Referências}

ABRUCIO, Fernando. A Lei de Acesso à Informação e a cidadania. Revista Época, 15 de junho de 2012. Disponível em: http://revistaepoca.globo.com/opiniao/fernando-abrucio/noticia/2012/06/lei-de-acessoinformacao-e-cidadania.html. Acesso em 20 set. 2018.

BOBBIO, Norberto. A era dos direitos. Trad. De marco Aurélio Nogueira. Rio de Janeiro: Campus, 2000. 240 p.

BRAGA, Lamartine. V.; ALVES, Welington. S., FIGUEIREDO, Rejane. M. C. \& SANTOS, Rildo. O papel do Governo Eletrônico no fortalecimento da governança do setor público. Revista do Serviço Público - RSP, 59(1), p. 05-21 janeiro/marco 2008. Disponível em: http://seer.enap.gov.br/index.php/ RSP/article/view/137/142. Acesso em: 10 Ago. 2019.

BRASIL. Constituição Federal de 1988. Constituição da República Federativa do Brasil de 5 de outubro de 1988. Vade Mecum. 15. ed. São Paulo: Saraiva, 2013.

BRASIL. Decreto $n^{\circ} 7.724$, de 16 de maio de 2012. Regulamenta a Lei ${ }^{\circ} 12.527$, de 18 de novembro de 2011, que dispóe sobre o acesso a informaçóes previsto no inciso XXXIII do caput do art. $5^{\circ}$, no inciso II do $\$ 3^{\circ}$ do art. 37 e no $\$ 2^{\circ}$ do art. 216 da Constituição. Disponível em: http://www.planalto.gov.br/ ccivil_03/_ato2011-2014/2012/decreto/D7724.htm. Acesso em: 19 Jul. 2019.

BRASIL. Lei no 8.666, de 21 de junho de 1993. Regulamenta o art. 37, inciso XXI, da Constituição Federal, institui normas para licitaçóes e contratos da Administração Pública e dá outras providências. Presidência da República. Disponível em: http://www.planalto.gov.br/ccivil_03/Leis/L8666cons.htm. Acesso em: 21 jul. 2019. 
Revista GESTO: Revista de Gestão Estratégica de Organizaçóes

Santo Ângelo | v. 8 | n. 2 | p. 43-55 | jul./dez. 2020 | DOI: http://dx.doi.org/10.31512/gesto.v8i2.56

BRASIL. Lei no 10.520, de 17 de julho de 2002. Institui, no âmbito da União, Estados, Distrito Federal e Municípios, nos termos do art. 37, inciso XXI, da Constituição Federal, modalidade de licitação denominada pregão, para aquisição de bens e serviços comuns, e dá outras providências. Presidência da República. Disponível em: http:/www.planalto.gov.br/ccivil_03/Leis/2002/L10520.htm. Acesso em: 21 jul. 2019.

BRASIL. Lei no 12.527, de 18 de novembro de 2011. Regula o acesso a informaçóes previsto no inciso XXXIII do art. $5^{\circ}$, no inciso II do $\$ 3^{\circ}$ do art. 37 e no $\$ 2^{\circ}$ do art. 216 da Constituição Federal; altera a Lei n 8.112, de 11 de dezembro de 1990; revoga a Lei no 11.111, de 5 de maio de 2005, e dispositivos da Lei no 8.159, de 8 de janeiro de 1991; e dá outras providências. Disponível em: http://www.planalto. gov.br/ccivil_03/_ato2011-2014/2011/lei/112527.htm. Acesso em: 13 Ago. 2019.

CORRÊA, Darcísio. A construção da cidadania: reflexões histórico-políticas. 2. ed. Ijuí: Editora UNIJUİ, 2000. 240 p.

JUSTEN FILHO, Marçal. Pregão: Comentários a Legislação do Pregão Comum e Eletrônico. 4. ed. São Paulo: Dialética, 2005. 351 p.

JUSTEN FILHO, Marçal. Curso de Direito Administrativo. 13. ed. São Paulo: Saraiva, 2018. 1632 p.

LAFER, Celso. A Reconstrução dos Direitos Humanos - um diálogo com o pensamento de Hannah Arendt. São Paulo: Companhia das Letras. 1991. 416 p.

MARTINS, Paulo. L. Acesso à informação: Um direito fundamental e instrumental. Acervo: Revista do Arquivo Nacional. Rio de Janeiro, v. 24, no 1, p. 233-244, jan/jun 2011. Disponível em: http://www2. an.gov.br/seer/index.php/info/article/view/476/399. Acesso em 21 Jul. 2019.

MELLO, Celso A. B. Curso de Direito Administrativo. 30. ed. São Paulo: Malheiros, 2013. 1136 p.

PÉREZ Luño, A. E. ¿Cibercidadani@o ciudadani@.com? Barcelona: Gedisa, 2004. 144 p.

PÉREZ Luño, A. Los Derechos Fundamentales. 11. ed. Madrid: Tecnos, 2013. 240 p.

PIOVESAN, Flávia. Temas de Direitos Humanos. 3. ed. São Paulo: Saraiva, 2009. 752 p.

SÁNCHEZ BRAVO, Álvaro. La administración eletrônica en Espanha. Revista do Direito. Revista do Programa de Pós-Graduação em Direito - Mestrado - PPGD - Universidade de Santa Cruz do Sul, n. 28, p. 90-122, jul./dez. 2007.

SÁNCHEZ BRAVO, Álvaro. A nova sociedade tecnológica: da inclusão ao controle social. A Europa é exemplo? Tradução Clovis Gorczevski. Santa Cruz do Sul: EDUNISC, 2010.

SILVA, José. A. Curso de Direito Constitucional Positivo. 32. ed. São Paulo: Malheiros, 2009.

VASCONCELO, Giovana G. V. A Garantia Constitucinal da Licitação na Modalidade Pregão na Forma Eletrônica. Revista Direito Público - Estudos conferências e notas. v.1, n. 13, p. 134 - 154, jul./ set. 2006. 
Democracia e Acesso à Informação nas Compras Públicas Municipais por Meio do Pregão Eletrônico Rosângela Angelin | Jocelit Zborowski

VAZ, José C. Internet e promoção da cidadania: a contribuição dos portais municipais. Sáo Paulo: Blucher Acadêmico, 2007. 